\title{
Progress in Southern Ocean Biology from the Indian Sector: Half-decadal (2009-13) Overview
}

\author{
S C TRIPATHY*, R K MISHRA and R K NAIK \\ National Centre for Antarctic and Ocean Research, Earth System Science Organization, Headland Sada, \\ Vasco-da-Gama, Goa 403 804, India
}

(Received on 17 May 2016; Accepted on 23 November 2016)

\begin{abstract}
This manuscript reviews the scientific insight gained from biological studies performed during Indian Southern Ocean Expeditions (ISOE) in the last 5 years. India's research activities in the Southern Ocean (SO) region emphasize the importance of enhanced understanding of the SO processes, biogeochemical cycles, marine productivity and global climate change scenario. Under the aegis of Ministry of Earth Sciences, Government of India, concerted efforts are put in place by NCAOR to carryout research in Indian sector of the SO since 2004, with a primary focus to comprehend the role (response) of the SO in regional and global climate variability. The findings discussed here are based on of a wide array of biological data collected during different expeditions ( $4^{\text {th }}$ to $7^{\text {th }}$ expedition conducted during 2009-13) which highlights: causal mechanisms of variability in phytoplankton community structure and productivity among frontal regions (i.e., Subtropical Front (STF), Subantarctic Front (SAF) and Polar Front (PF)), patterns of phytoplankton biomass distribution within and among the fronts, role of diatoms in deciphering environmental change, food-web dynamics, bio-optical characterisation of water column, response of bacteria and phytoplankton to micronutrient amendments, biochemical profiling of squids, distribution of Antarctic krill, and occurrence of different marine mammals/birds in the above frontal regions. Here, we attempt to succinctly capture the findings of published literature engendered from ISOE to put forward our present perception of this lesser-understood region in the SO. This document is expected to contribute to an increased understanding of the Indian sector of SO, besides providing the much needed visibility to our ongoing scientific endeavours among the international community.
\end{abstract}

Key words: Southern Ocean; Indian Sector; Plankton; Productivity; Biogeochemistry; Climate Change

\section{Introduction}

Each oceanic region has different significance in influencing the global climate change scenario with their potential for drawing-down the atmospheric $\mathrm{CO}_{2}$ (Sabine et al., 2004). In this context, the Southern Ocean (SO), being the world's largest high-nutrient low-chlorophyll (HNLC) regions, plays a significant role as a sink for atmospheric $\mathrm{CO}_{2}$ via its solubility and prevailing biological pumps (Chisholm et al., 2001). It thus plays a pivotal role in the global carbon cycle and climatic regulations through biogeochemical fluxes of carbon, nutrients etc. from the ocean surface to the deep interior. The efficiency of the biological pump depends on a range of environmental and biological factors (such as type of phytoplankton/ zooplankton inhabiting), which in turn are influenced by climate change. It is observed that the productivity in SO regions is closely related to the hydrodynamics across the fronts and convergence zones, thereby varying the phytoplankton, the prey-predator relationship and food-web structure and biogeochemical cycle (Pollard et al., 2002; Kostianoy et al., 2004).

The biogeochemistry and circulation of the SO are widely viewed to be sensitive to perturbation by climate change (Sarmiento et al., 1998). The SO ecosystems are structured broadly by latitude, or more precisely, by the quasi-zonal structure of the Antarctic Circumpolar Current (ACC) (Grant et al., 2006; Griffiths et al., 2009) and by the bottom topography/

*Author for Correspondence: E-mail: sarat@ncaor.gov.in 
depth. The plankton community of small flagellates, coccolithophores and small zooplankton prevail at the silica limited waters of the Subantarctic Front (SAF) and Subtropical Front (STF), and diatoms become increasingly dominant towards south in the HNLC waters at Polar Front (PF) and the coastal Antarctica, where primary production is believed to be limited by availability of trace nutrients (presumably iron). These aspects drew the interest of researchers from all over the world to study such dynamic ecosystem for climate change, thus resulting in several large scale experiments (i.e., SOIREE, SOFeX, EiFeX, LOHAFEX, WOCE, JGOFS, RACER, SO-GLOBEC and BROKE-West survey etc.) in Pacific and Atlantic sector of the SO; nevertheless, the Indian sector of SO remained underexplored.

In 2004, under the sponsorship and support of Ministry of Earth Sciences (MoES), Government of India, the National Centre for Antarctic and Ocean research (NCAOR), Goa initiated a national programme to study the Indian sector of SO (Fig. 1) for an improved understanding of the SO processes, biogeochemical cycles, marine productivity and its response to global climate change. Till date, eight multiinstitutional and multi-disciplinary expeditions were undertaken to the SO during the austral summer. Standard methodologies were adopted for measurement and analyses for respective variables (for details please refer the relevant published article). Outcome of the expeditions are published in the technical/scientific reports published by NCAOR and in the peer-reviewed journals of national and international repute. The present article aims to summarize the significant scientific results obtained from biological studies conducted during different expeditions from 2010 to 2013 (Table 1).

\section{Findings from Different Expeditions}

Over the years different ISOEs were carried out in Indian sector $\left(45^{\circ} \mathrm{E}-77^{\circ} \mathrm{E}, 40^{\circ} \mathrm{S}-69^{\circ} \mathrm{S}\right)$ of the SO during austral summer (January-March). Cruise tracks were designed to spatially cover meridional and zonal sections for sampling across and along the frontal regions, respectively. During some expeditions, time series measurements at particular locations were also conducted to resolve the temporal variations in SO biological processes. The multidisciplinary observations were mainly concentrated between the

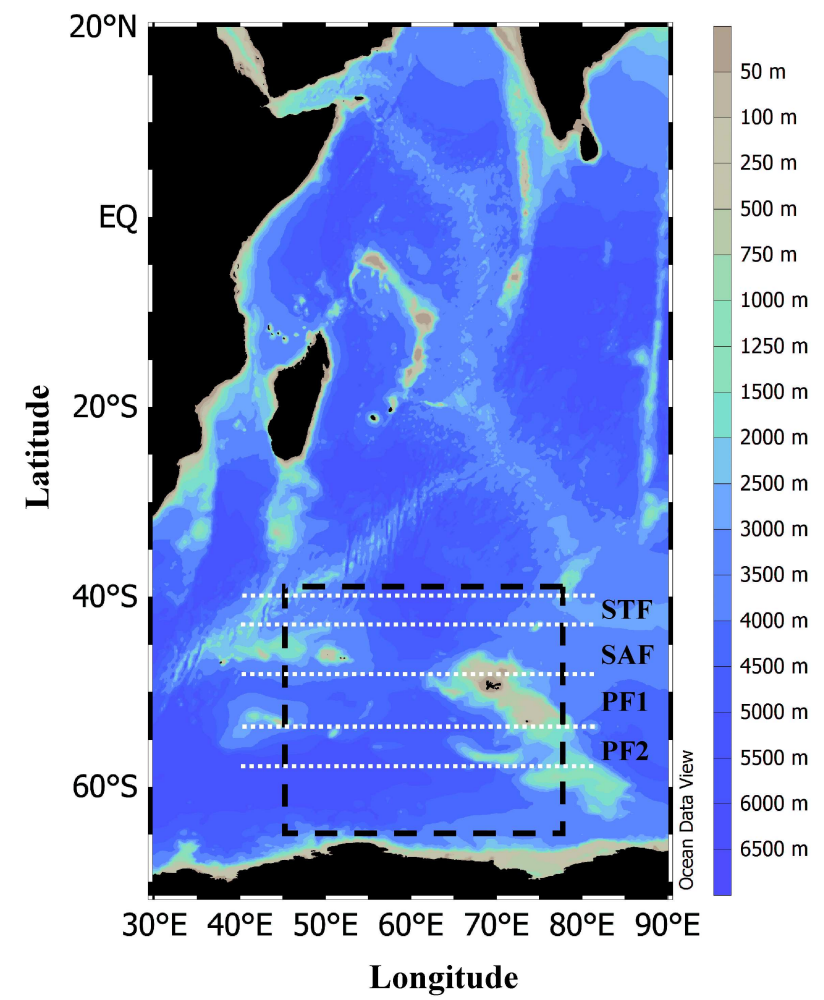

Fig. 1: Map showing boundary of the Indian sector of Southern Ocean (dashed-line rectangle box). The dotted white lines indicate the location of different frontals regions, whereas the colour bar indicates depth of the bottom topography

subtropical $\left(40^{\circ} \mathrm{S}\right)$ and coastal waters off Antarctica. Findings pertaining to biological studies from $4^{\text {th }}$ to $7^{\text {th }}$ expedition are discussed hereunder:

\section{Findings from the $4^{\text {th }}$ ISOE (2009-10)}

This expedition was aimed at studying the Polar Front (PF) and coastal Antarctic zone $\left(66^{\circ} \mathrm{S}\right)$ of the Indian sector of $\mathrm{SO}$, which revealed interesting facts about the prevailing food-web dynamics, variability in phytoplankton biomass/chlorophyll a (Chl-a) and primary productivity (PP). Pavithran et al. (2012) observed contrasting pattern of Chl-a distribution within the PF (PF1: $52^{\circ} \mathrm{S}$ and PF2: $\left.56^{\circ} \mathrm{S}\right)$, in spite of nutrients and light conditions not being limiting at both the regions. Hence, they attributed the reason for the observed contrasting pattern in Chl-a to the dominance of microbial food-web and conventional food-web at $\mathrm{PF} 1$ and PF2, respectively. Chl-a increased from $40^{\circ} \mathrm{S}$ to $52^{\circ} \mathrm{S}$ along the $52^{\circ} 30^{\prime} \mathrm{E}$ meridional transect except the $48^{\circ} \mathrm{S}$. The subsurface chlorophyll maxima (SCM) 
Table 1: General information about the Indian Southern Ocean Expeditions (ISOE)

\begin{tabular}{|c|c|c|c|c|}
\hline Expedition & Duration & Study area* & Variables measured* & Sampled stations* \\
\hline ISOE-4 & $\begin{array}{l}\text { 12-Jan-2010 to } \\
25-M a r-2010\end{array}$ & $\begin{array}{l}40^{\circ} \mathrm{S} 66^{\circ} \mathrm{S} \\
47.5^{\circ} \mathrm{E} 57.5^{\circ} \mathrm{E} \\
(\mathrm{PF} 1, \mathrm{PF} 2 \& \\
\text { coastal Antarctica) }\end{array}$ & $\begin{array}{l}\text { Phytoplankton pigment (chlorophyll a), primary } \\
\text { production }\left({ }^{14} \mathrm{C}\right) \text {, phytoplankton/zooplankton } \\
\text { taxonomy, bacterial carbon demand, Antarctic krill } \\
\text { sampling for studying its distribution }\end{array}$ & 21 stations \\
\hline ISOE-5 & $\begin{array}{l}\text { 24-Jan-2011 to } \\
\text { 10-Mar-2011 }\end{array}$ & $\begin{array}{l}40^{\circ} \mathrm{S} 60^{\circ} \mathrm{S} \\
47^{\circ} \mathrm{E} 57.5^{\circ} \mathrm{E} \\
(\text { Focus on } \mathrm{STF}+\mathrm{PF})\end{array}$ & $\begin{array}{l}\text { Phytoplankton pigments (HPLC), primary } \\
\text { production }\left({ }^{14} \mathrm{C}\right) \text {, phytoplankton/zooplankton } \\
\text { taxonomy, bio-optical studies, bacterial production } \\
\text { and activity, marine mammals, seabirds, squid jigging }\end{array}$ & $\begin{array}{l}2 \text { meridional transects } \\
\text { along } 57.5^{\circ} \mathrm{E} \text { and } 47^{\circ} \mathrm{E} \\
\text { including the STF and PF. } \\
\text { Total } 26 \text { stations ( } 2 \text { time } \\
\text { series: } 1 \text { each at STF and } \\
\text { PF) }\end{array}$ \\
\hline ISOE-6 & $\begin{array}{l}\text { 23-Dec-2011 to } \\
\text { 06-Feb-20 }\end{array}$ & $\begin{array}{l}53.5^{\circ} \mathrm{E} 58.5^{\circ} \mathrm{E} \\
40^{\circ} \mathrm{S} 53^{\circ} \mathrm{S} \\
\text { (Focus on STF) }\end{array}$ & $\begin{array}{l}\text { Phytoplankton pigments (HPLC), primary production } \\
\text { zooplankton taxonomy, bio-optical studies, bacterial } \\
\left({ }^{14} \mathrm{C}\right) \text {, phytoplankton/production and activity, } \\
\text { squid jigging and biochemical evaluation. Observations } \\
\text { on atmospheric } \mathrm{CO}_{2} \text { conc., atmospheric and dissolved } \\
\delta^{13} \mathrm{C} \text { were started }\end{array}$ & $\begin{array}{l}09 \text { stations } \\
\text { (1 time series at STF) }\end{array}$ \\
\hline ISOE-7 & $\begin{array}{l}\text { 11-Jan-2013 to } \\
\text { 27-Feb-2013 }\end{array}$ & $\begin{array}{l}40^{\circ} \mathrm{S} 56.5^{\circ} \mathrm{S} \\
47.5^{\circ} \mathrm{E} 57.5^{\circ} \mathrm{E} \\
\text { (Focus on } \mathrm{PF} \text { ) }\end{array}$ & $\begin{array}{l}\text { Phytoplankton pigments (HPLC), primary production } \\
\left({ }^{14} \mathrm{C},{ }^{13} \mathrm{C}\right),{ }^{15} \mathrm{~N} \text {-nitrogen uptake rates, phytoplankton/ } \\
\text { zooplankton taxonomy, bio-optical studies, bacterial } \\
\text { production and activity }\end{array}$ & $\begin{array}{l}19 \text { stations ( } 2 \text { time series: } \\
1 \text { each at STF and PF) }\end{array}$ \\
\hline
\end{tabular}

*Some of the information (parameters measured, stations sampled) are restricted to biological sampling stations only. For sampling $O R V$ Sagar Nidhi was used for all expeditions and observations were made with prime importance to the frontal regions. For details please refer technical reports of the respective ISOE

depths varied from $50 \mathrm{~m}$ at $39^{\circ} \mathrm{S}$ to $10 \mathrm{~m}$ at $43^{\circ} \mathrm{S}$. However, the column Chl-a concentration increased from $0.72 \mathrm{mg} \mathrm{m}^{-3}$ at $48^{\circ} \mathrm{S}$ to $5.38 \mathrm{mg} \mathrm{m}^{-3}$ at $52^{\circ} \mathrm{S}$ indicating that the colder water in the south was more productive compared to the waters of the north of Subantarctic Front (SAF) (Pavithran et al., 2014a). In the coastal region the Chl-a showed patchy and distinct variation between stations at the surface and varied from 0.39 to $4.9 \mathrm{mg} \mathrm{m}^{-3}$ and gradually increased from the west $\left(51^{\circ} 14^{\prime} \mathrm{E}\right)$ to east $\left(53^{\circ} 32^{\prime} \mathrm{E}\right)$. Based on scanning electron microscope studies, it was observed that the coccolithophores species Emiliania huxleyi was higher in abundance at the north of Subtropical Front (STF) and decreased its concentration towards south of SAF. Furthermore, it was found that the species survived better at a higher temperature $\left(18.4-15.3^{\circ} \mathrm{C}\right)$, salinity (35.45-35.29) and low nutrients, high $\mathrm{pH}$ and high solar radiation conditions. The north-south trend of decreased calcification of E. huxleyi reflected the role of temperature and salinity as major factors for controlling the biogeographical distribution of coccolithophores (Patil et al., 2014). Shetye et al., 2014 observed that the diatom Corethron criophilum was the dominant species in the coastal region under low temperature $\left(\sim 1.5^{\circ} \mathrm{C}\right)$ and lower salinity 33 . The authors suggested the possibility of a $\mathrm{CO}_{2}$-driven shift in phytoplankton dominance in the future due to elevated $\mathrm{CO}_{2}$ levels (decreased $\mathrm{pH}$ ) in the $\mathrm{SO}$.

During this period, $\mathrm{PP}$ varied from 0.03 to 20.20 $\left(3.09 \pm 4.89 \mathrm{mg} \mathrm{C} \mathrm{m}^{-3} \mathrm{~d}^{-1}\right)$ in the water column, and like Chl-a didn't show any north-south trend. The PP values for polar waters were higher than that of the offshore stations. The PP peak was observed at $\sim 30$ $\mathrm{m}$, which did not coincide with the Chl-a peaks indicating that factors other than Chl-a were controlling $\mathrm{PP}$ in this region. Integrated PP (IPP) varied from $159-1083 \mathrm{mg} \mathrm{C} \mathrm{m}^{-2} \mathrm{~d}^{-1}$, with lowest values at $44^{\circ} \mathrm{S}$ (a typical HNLC region along with Si-limitation); whereas highest IPP was observed at the coastal region $\left(66^{\circ} \mathrm{S}\right)$. High PP in the coastal region could possibly be due the influence of melt-water intrusion which brings the micronutrients (i.e., Fe, Co etc.), thus triggering an enhancement of biomass and productivity (Pavithran et al., 2014a). Comparison of Chl-a and PP data from PF and coastal Antarctic region indicated discrepancy in high Chl-a and relatively low PP in the coastal region by Tripathy et $a l .$, 2014. The authors depicted that large-sized 
phytoplankton (i.e., diatoms), dominant in coastal region, could package more intra-cellular pigments when compared to smaller phytoplankton $(<10 \mu \mathrm{m})$, consequently there is decrease in their light-absorption/ photosynthetic efficiency (Fig. 2), resulting in lower surface PP, which is otherwise expected to be higher

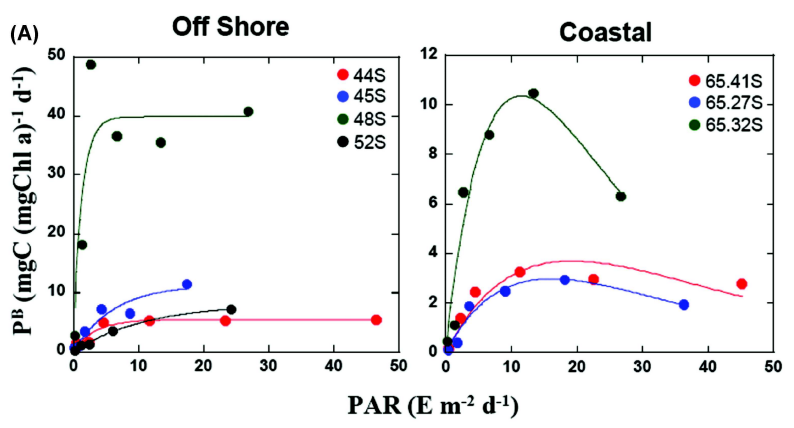

(B)

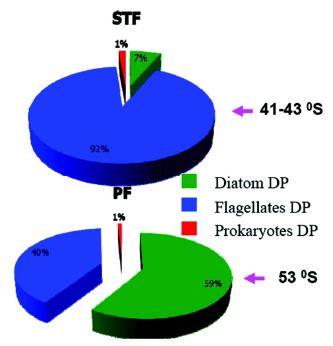

Fig. 2: (A) Photosynthesis (biomass-specific productivity)irradiance curve in the water column showing inhibition in the surface layer in the coastal stations, (B) schematic of package effect (left panel) and percentage contribution of different diagnostic pigments at STF $\left(41^{\circ}-43^{\circ} S\right)$ and $\mathrm{PF}\left(53^{\circ} \mathrm{S}\right)$

in the presence of elevated Chl-a.

The mesozooplankton such as copepod and copepodites were dominant over all the fronts and zones sampled, however the salps were observed from surface to depth of $300 \mathrm{~m}$ and were distinct at south of PF region. In the offshore water both copepod and copepodites showed higher abundance at the mixed layer, and biomass increased towards PF compared to the SAF and STF region. Results indicated that increased phytoplankton biomass facilitated a higher increase of mesozooplankton biomass at PF than at SAF and STF (Pavithran et al., 2014a).

Like phytoplankton, bacterial carbon demand (BCD) varied significantly between the fronts $(p=$ $0.03, \mathrm{df}=3)$ and depths $(p=0.003, \mathrm{df}=6)$ and ranged from 0.05 to $0.22 \mu \mathrm{g} \mathrm{C}^{-1} \mathrm{~h}^{-1}$. Similar to contrasting pattern of Chl-a, BCD was higher at PF1 (2.91 mg C $\left.\mathrm{m}^{-2} \mathrm{~h}^{-1}\right)$ than at PF2 $\left(1.55 \mathrm{mg} \mathrm{C} \mathrm{m}^{-2} \mathrm{~h}^{-1}\right)$ implying that contribution of microbial loop (conversion of dissolved organic matter to secondary biomass) at PF2 was more pronounced due to lower bacterial respiration rate $\left(0.83 \mathrm{mg} \mathrm{C} \mathrm{m}^{-2} \mathrm{~h}^{-1}\right)$. Integrated bacterial growth efficiency was higher at PF2 (8.95) as compared to that of PF1 (7.42), further signifying the net contribution of PF2 to the microbial loop (Krishnan et al., 2014).

In SO food chain, the link between producers (phytoplankton) and higher animals are maintained by the krill. The krill is the largest euphausiid, widely distributed in SO and plays a key role in this ecosystem as a feed especially for whales, seals and birds. In the surface layers, three species of krill (Euphausia lucens, E. frigida and Thysanoessa sp.) were observed during the expedition (Manjebrayakath, 2014). No stage of the Antarctic krill (E. superba) was present in the surface layers suggesting that the species may not be migrating up to the surface during vertical migration. E. frigida (52\%) was the most dominant species followed by Thysanoessa sp. (27\%) and E. lucens (21\%). The Thysanoessa sp. was restricted between $40^{\circ} \mathrm{S}$ and $46^{\circ} \mathrm{S}$, whereas the $E$. frigida was abundant and widely distributed from $40^{\circ} \mathrm{S}$ and $66^{\circ} \mathrm{S}$ probably due to its wider tolerance to temperature.

\section{Findings from the $5^{\text {th }}$ ISOE (2010-11)}

Two meridional sections (along $57.5^{\circ} \mathrm{E}$ and $47^{\circ} \mathrm{E}$ ) including the STF and PF were covered during this expedition. Observations were also carried out along one zonal section $\left(60^{\circ} \mathrm{S}\right)$. Between the two time series (72 h @3 h interval) stations, the PF was more productive than STF. Surface Chl-a was observed to be relatively low at STF $\left(0.1-0.4 \mathrm{mg} \mathrm{m}^{-3}\right)$ compared to $\mathrm{PF}\left(0.2-0.45 \mathrm{mg} \mathrm{m}^{-3}\right)$. The water column-integrated Chl-a was also lower at STF $\left(2.2-4.4 \mathrm{mg} \mathrm{m}^{-2}\right)$ compared to PF (4.2-7.3 $\mathrm{mg} \mathrm{m}^{-2}$ ). The southward increasing trend of phytoplankton biomass and shoaling of sub-surface chlorophyll maximum (SCM) was noticed between $40^{\circ} \mathrm{S}$ and $60^{\circ} \mathrm{S}$. Chl-a values at SCM were in the range of 0.7 to $1.0 \mathrm{mg} \mathrm{m}^{-3}$ and the depth of SCM was always deeper than mixed layer depth (MLD). Along the transect $47^{\circ} \mathrm{E}$ surface distribution of Chl-a showed a southward increasing trend. The SCM at STF varied between 60 and $80 \mathrm{~m}$ with Chl-a ranging between $0.4 \mathrm{mg} \mathrm{m}^{-3}\left(40^{\circ} \mathrm{S}\right)$ and $1.2 \mathrm{mg} \mathrm{m}^{-3}$ 
$\left(60^{\circ} \mathrm{S}\right)$. On the other hand, at $57.5^{\circ} \mathrm{E}$ transect $\mathrm{Chl}-\mathrm{a}$ ranged between 0.2 and $0.5 \mathrm{mg} \mathrm{m}^{-3}$ indicating lower Chl-a compared to the western margin (more productive). Surface $\mathrm{Chl}-\mathrm{a}$ along $57.5^{\circ} \mathrm{E}$ was more uniform and the zonal variations across $60^{\circ} \mathrm{S}$ showed more productivity than the eastern margins (Pavithran et al., 2014b), which could be due to the availability of micronutrients because of proximity to the African continent. Phytoplankton diagnostic pigment-based analysis using CHEMTAX showed the cross-front distribution of phytoplankton communities and the relative contribution from major taxonomic groups to total biomass at STF and PF (Garcia et al., 2014; Mendes et al., 2015). Cyanobacteria and prochlorophytes dominated the total Chl-a in the STF, the haptophyes dominated the SAF region and diatoms were dominant at the PF. It was found that the spatial distribution of phytoplankton groups varied along ocean surface thermal gradients. Moreover, latitudinal differences in temperature, nutrients, variation in MLD, prevailing wind pattern and herbivory are probably the other parameters that distinguish the phytoplankton assemblages in this region (Mendes et al., 2015).

Time series measurements from this expedition highlighted the significance of deep chlorophyll maximum (DCM) in explaining the variability of IPP (Tripathy et al., 2015). At the PF, they observed a well-defined temperature minimum layer (TML), which was the winter residue of Antarctic Surface Water (AASW), between 50 and $320 \mathrm{~m}$. The DCM at the PF $(\sim 75 \mathrm{~m})$ was more prominent than that at the STF and coincided with the upper boundary of the TML. The elevated Chl-a in DCM is believed to result from the proliferation of the low-light adapted phytoplankton (shade flora) triggered by higher concentrations of micronutrients (presumably $\mathrm{Fe}$ ) found in the winter remnant of the AASW than in the overlying mixed layer. Due to the presence of a strong DCM the average column-integrated Chl-a was nearly 2 times higher at the PF than at the STF yielding 1.4 times higher IPP at the PF $\left(211 \mathrm{mg} \mathrm{C} \mathrm{m}^{-2} \mathrm{~d}^{-1}\right)$ compared to the STF $\left(152 \mathrm{mg} \mathrm{C} \mathrm{m}^{-2} \mathrm{~d}^{-1}\right)$. Higher Chl-a and PP at the PF was related to the dominance of diatoms. Owing to their higher sinking rate, the diatoms with sequestered $\mathrm{CO}_{2}$, would generate substantial export production/flux, thereby making the $\mathrm{PF}$ region as a potential sink for atmospheric $\mathrm{CO}_{2}$ (Tripathy et al., 2015).
Similar to the previous expedition the mesozooplankton showed clear diel variation in the STF and PF with a predominance of copepods (95\%), indicating their adaptability to different environments and food availability (Pillai et al., 2014). A total of 18 and 12 taxa of copepods were observed at the STF and the $\mathrm{PF}$, respectively, with more temporal variation in species abundance at STF than at PF. Vertical distribution of biomass at both STF and PF showed a decreasing trend from surface to deeper layer. An exclusive abundance of salps and cyclopoid copepod was also noticed in the STF, indicating a rare predatorprey relationship (between salps and sapphirina) existing in this region. Due to the abundance of salps, an exceptional increase in biomass was noticed occasionally at both the frontal regions by Pillai et al. (2014). They reported that (i) in both the transects $\left(57.5^{\circ} \mathrm{E}: 37^{\circ} \mathrm{S}-60^{\circ} \mathrm{S}\right.$ and $47^{\circ} \mathrm{E}: 42^{\circ} \mathrm{S}-60^{\circ} \mathrm{S}$ ) a general increase in zooplankton biomass was observed towards southern latitudes, mainly due to occurrence and increase in density of macro-zooplankton components such as euphausiids, amphipods and salps; (ii) the higher abundance of meso-zooplankton observed at PF compared to STF was probably related to the seasonal phytoplankton availability in that area; (iii) the food-web structure appears to be more dynamic and multivorous at the STF comprising both conventional and microbial modes; whereas, the conventional food-web was more active at the PF, dominated by the herbivores.

Isolation and characterization of microalgae and bacteria were carried out from two transects (i.e., $45^{\circ} \mathrm{S} 57.30^{\circ} \mathrm{E}$ and $48^{\circ} \mathrm{S} 57.30^{\circ} \mathrm{E}$ ). This study focused on hydrogen production and antibacterial activity against some gram-positive and gram-negative pathogenic bacteria by the isolated microalgae (Bandopadhyay et al., 2014). It was observed that isolates from $45^{\circ} \mathrm{S}$ and $57^{\circ} 30^{\prime} \mathrm{E}$ at $45 \mathrm{~m}(\mathrm{P} 1)$ has more hydrogen producing capacity than isolates from $48^{\circ} \mathrm{S}$ and $57^{\circ} 30^{\prime} \mathrm{E}$ at $30 \mathrm{~m}(\mathrm{P} 2)$. In the case of antibacterial activity chloroform and ethanol extracts of $\mathrm{P} 1$ have maximum activity against gram-positive bacteria than gram-negative bacteria. Ethyl acetate and ethanol extracts of $\mathrm{P} 2$ had maximum inhibition against pathogenic $E$. coli, a gram-negative bacterium. A total of 57 bacteria were isolated and found that some of the bacteria were pigmented and some were exopolysaccharide producing. 
Bio-optical properties in the water column were studied by Shaju et al. (2014). They found a strong linear relationship between phytoplankton specific absorption (at 440 and $665 \mathrm{~nm}$ ) vs Chl-a $\left(\mathrm{R}^{2}=0.96\right.$ and $\left.\mathrm{R}^{2}=0.94\right)$ and opined that phytoplankton absorption can be largely explained/determined by phytoplankton biomass in this region. Absorption by coloured dissolved organic matter (CDOM) was relatively high in the blue regions at par with phytoplankton absorption. In contrast the CDOM absorption was less compared to the phytoplankton absorption. However the CDOM absorption variation did not show any change with respect to Chl-a or salinity implying that CDOM production may be mainly related to the microbial activity. The non-algal suspended particulate matter (SPM), CDOM and Chla co-varied indicating that occurrence of waters dominated by one or two of these absorbing component was highly improbable. Ternary diagram for absorption (at 440-560 nm) by three components (Fig. 3) showed that most samples (73\%) located within the central zone, thus these three components co-vary to some extent. No clear separation of Case 1 and Case 2 waters could be done due to high contributions from CDOM in this region (Shaju et al., 2014).

For observations on atmospheric $\mathrm{CO}_{2}$ concentration, the $\delta^{13} \mathrm{C}$ in atmospheric $\mathrm{CO}_{2}$ sampled in the glass flask and the $\delta^{13} \mathrm{C}$ of dissolved inorganic carbon (DIC) in sea surface water samples collected

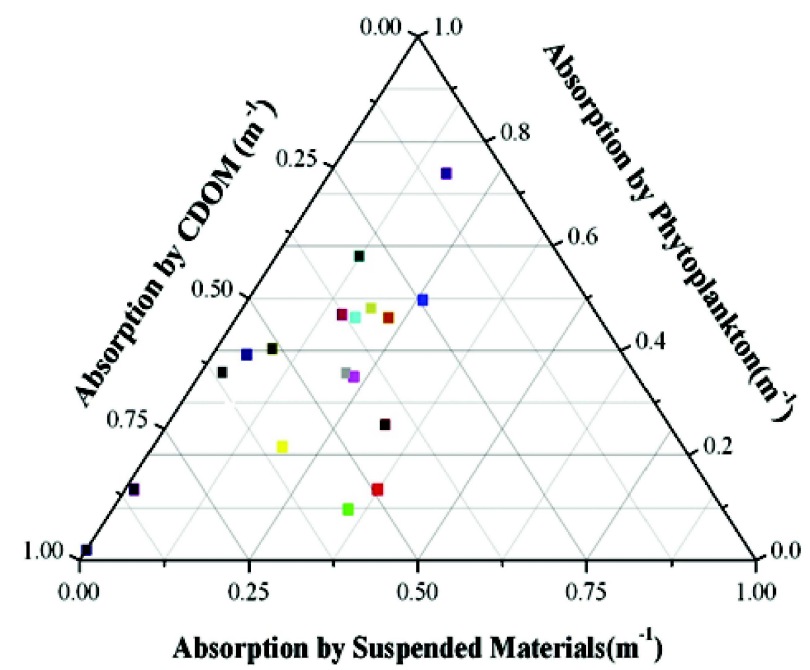

Fig. 3: Relative contribution of absorption by bio-optical substances in the Indian sector of Southern Ocean during 2010-11 austral summer across the latitudes (Prasanna et al., 2014) have been carried out (Table 1). The study found that in the SO the region near south STF $\left(46^{\circ} \mathrm{S}\right)$ was the zone of $\mathrm{CO}_{2}$ source where photosynthetic activity was not enough to convert the $\mathrm{CO}_{2}$ into primary production. The PFZ $\left(52^{\circ} \mathrm{S}\right.$ to $\left.56^{\circ} \mathrm{S}\right)$ is the region of $\mathrm{CO}_{2}$ sink where productivity is mainly responsible for the $\mathrm{CO}_{2}$ uptake by the ocean. The different composition of $\mathrm{CO}_{2}$ based on the source isotopic signature was identified based on this study. Furthermore, analysing three years (including this year) data Prasanna et al. (2015) showed that the major source of $\mathrm{CO}_{2}$ degassed from the ocean is from the dissociation of DIC, which is mainly caused by ocean acidification, which is expected to be intensify in future.

Any change in environmental settings would likely exert an influence on the distribution of biological species, may it be plankton or higher animals, since there are links between oceanographic variables and the fauna like marine mammals, sea birds and squids, which being the top predators, play a crucial role in SO ecosystem. Opportunistic visual surveys of marine mammals were conducted (Jayabaskaran, 2014). During this expedition a pod (6) of Minke whales (Balaenoptera bonaerensis) and a pod (7) of Killer whales (Orcinus orca) were sighted. Though about 30 species of marine mammals have been reported from the SO region as whole, information from the Indian sector of SO is very limited and so far only 9 species of marine mammals have been reported by Indian scientists. About 18 species of sea birds (Albatross and Petrels which are common in the SO) between $40^{\circ} \mathrm{S}$ to $66^{\circ} \mathrm{S}$ and only one bird of Antarctic Brown Skua (Stericorarius lonnbergi) were sighted. The popular flying squid (Todarodes filippovae), having high economic value, were observed in the STF $\left(35^{\circ} \mathrm{S}-38^{\circ} \mathrm{S}\right.$ and $\left.66^{\circ} \mathrm{E}-77^{\circ} \mathrm{E}\right)$ region. Bioaccumulation of heavy metals tested in $T$. filippovae tissues in the mantle of the species which are within the permissible limits recommended for human consumption. The cccurrence of coral fragment indicated the presence of cold water coral, especially in $\mathrm{Ob}$ and Lena seamounts regions.

\section{Findings from the $6^{\text {th }}$ ISOE (2011-12)}

During this expedition the STF was studied extensively with meridional transect and time series observations. Total Chl-a varied from 0.03 to $1.19 \mathrm{mg} \mathrm{m}^{-3}$ and both these values were observed at the STF. The 
taxonomic composition of phytoplankton community showed dominance of flagellates at the STF and it decreased towards higher latitudes and switched to dominance of diatoms at the PF, whereas photosynthetic prokaryotes were almost below detectable level at the PF (Naik et al., 2015a). The marked variation of community at the STF and the PF were linked to the environmental settings at respective stations and the variation was also explained by canonical correspondence analysis (CCA) which indicated the preference of environmental variables for each group (Fig. 4). The

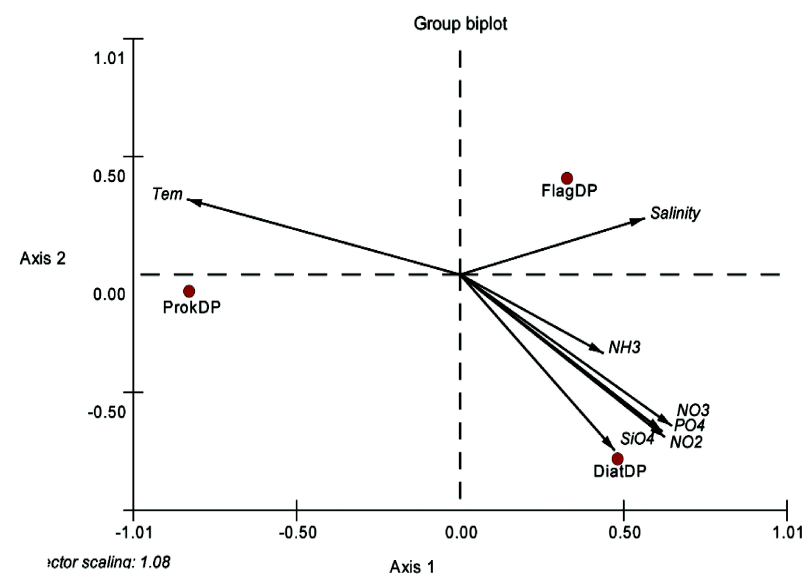

Fig. 4: Canonical correspondence analysis ordination diagram group biplot explaining the relationship between phytoplankton group (based on diagnostic pigment indices) and environmental variables at STF and $\mathbf{P F}$

prokaryotes showed the preference for temperature and diatoms for elevated nutrients, whereas the flagellates preferred intermediate temperature and salinity condition. The water column stability also played a role in phytoplankton distribution. Column stability was high at the STF (shallow MLD) with lower nutrient levels and low at the PF (deep MLD) with high nutrient levels supporting flagellates at the STF and diatoms at the PF, respectively. Diagnostic pigment indices and CHEMTAX was used to analyse the time series $(48 \mathrm{~h})$ samples from the STF, which depicted oscillation in phytoplankton community structure at 6 hourly intervals at $120 \mathrm{~m}$ depth. The oscillation between flagellates (nanoplankton) to prokaryotes (picoplankton) and then to diatoms (microplankton) coincided with significant variation in nitrate and phosphate concentrations, along with an increase in abundance of grazer community. The observed small interval variation in phytoplankton community was controlled passively by bottom-up factors due to weak dissipation rate and actively by top-down factors due to the presence of ciliates and heterotrophic dinoflagellates (Naik et al., 2015b).

The PP was estimated both at the STF and the $\mathrm{PF}$ along $57^{\circ} 30^{\prime} \mathrm{E}$, which showed noticeable spatial variation at the STF with high surface and sub surface values at both $41^{\circ} \mathrm{S}\left(3.01 \mathrm{mg} \mathrm{C} \mathrm{m}^{-3} \mathrm{~d}^{-1}\right)$ and $43^{\circ} \mathrm{S}$ (3.28 $\mathrm{mg} \mathrm{C} \mathrm{m}^{-3} \mathrm{~d}^{-1}$ ). The STF was shown to be three fold more productive than the PF by Haridevi et al. (2015). They observed high variability in PP within the STF at longitudes $53^{\circ} 30^{\prime} \mathrm{E}$ and $57^{\circ} 30^{\prime} \mathrm{E}$ along $43^{\circ} \mathrm{S}$ latitude, which could be ascribed to variation in composition of phytoplankton group. Diatoms and dinoflagellates were dominant in earlier and later sampling, respectively. Photosynthesis-Irradiance (PI) experiment carried out at the same stations for $10 \mathrm{~m}$ and $50 \mathrm{~m}$ samples showed higher uptake rate at $53^{\circ}$ $30^{\prime} \mathrm{E}$ than at $57^{\circ} 30^{\prime} \mathrm{E}$. Extended day length was found to influence the PP. Towards the dusk a secondary peak in PP $\left(0.32 \mathrm{mg} \mathrm{C} \mathrm{m}^{-3} \mathrm{~h}^{-1}\right)$ was observed, which could be attributed to the production after photo-repair or due to the existence of low-light adapted phytoplankton capable of fixing $\mathrm{CO}_{2}$ at dim light.

The micro-zooplankton abundance was more dominant at the STF (avg. $764 \times 10^{3}$ ind. $\mathrm{m}^{-2}$ ) than at the PF (avg. $471 \times 10^{3}$ ind. $\mathrm{m}^{-2}$ ). The composition also differed significantly between the two regions with heterotrophic dinoflagellates and ciliates being dominant at the STF. In contrast to the high microzooplankton abundance at the STF the mesozooplankton biovolume was higher at the PF (PF: avg. $0.245 \mathrm{ml} . \mathrm{m}^{-3}$; STF: avg. $0.105 \mathrm{ml} . \mathrm{m}^{-3}$ ). However, the diversity of meso-zooplankton was more at the STF (12) compared to the PF (8), indicating disparity in the food-web structure between the two fronts (Minu et al., 2015). Copepods were predominant at all depths in both the frontal regions with occasional appearance of salps and euphausiids. Time series observations showed significant diurnal variations of the mesozooplankton standing stock in the mixed and thermocline layer compared to the deeper layers of the STF. High standing stock was observed early in the morning and late night depicting the effect of light on vertical migration of the zooplankton. 
Using the ex-situ experimental approach the response of bacteria and phytoplankton to micronutrient amendments (i.e., $\mathrm{Co}, \mathrm{Cu}, \mathrm{Fe}$ and their mixture) were studied at the STF. Results indicated that availability of micronutrients, particularly $\mathrm{Fe}$, affects the bacterial abundance and community composition, but not the phytoplankton growth at the STF (Ramaiah et al., 2015a). Preponderance of only a few bacterial prototypes was observed on amendment of micronutrients and this could be due to preferential and/or versatile utilisation of exogenously added micronutrient. In addition to this, biochemical characteristics and numerical profiling analysis using $16 \mathrm{~S}$ rRNA marker gene yielded several clusters. This analysis revealed the prevalence of only few prototypes such as Firmicutes ( 90\%) and Gammaproteobacteria ( 10\%) in the DCM zone of this STF location (Ramaiah et al., 2015b).

Squid jigging operations carried out during this expedition explained the discontinuity length-weight relationship in the species Sthenoteuthis bartramii (Pravin et al., 2015). The morphometric measurements were taken for understanding the relationship between species from different geographical areas. A total of 56 specimens were identified, out of which 19 were male and their length ranged between $21.2-32.8 \mathrm{~cm}$ (avg. $29 \mathrm{~cm}$ ) and weight from $230-1020 \mathrm{~g}$ (mean $698 \mathrm{~g}$ ). The length of females ranged from $19.4-44.9 \mathrm{~cm}$ (mean $31 \mathrm{~cm}$ ) and weight from $115-2410 \mathrm{~g}$ (mean $847 \mathrm{~g}$ ). The results confirm that both male and female $S$. bartramii showed an isometric growth pattern. The observed fluctuation in the growth might be due to the variation in ecology, geographic conditions and food availability. Two flying squids such as Todarodes filippovae and Ommastraphes bartramii were observed for biochemical evaluation for nutritional properties. Except the moisture content, the ash, protein and fat were higher in $T$. filippovae than $O$. bartramii. Biochemical profiling of squids indicated that omega3 polyunsaturated fatty acids were high in both $O$. bartramii and $T$. filippovae, which are commonly found in the SO (Remyakumari et al., 2015).

\section{Findings from the $7^{\text {th }}$ ISOE (2012-13)}

This expedition encompasses observations along the regular meridional track $\left(57^{\circ} 30^{\prime} \mathrm{E}\right)$ and in the $\mathrm{PF}$ region. Chl-a ranged from 0.2 to $0.9 \mathrm{mg} \mathrm{m}^{-3}$ and increased from STF to PF1 and then decreased at the PF2, indicating PF1 as more productive than other frontal zones. Variation in DCM was observed in various fronts and it was $50 \mathrm{~m}$ at the STF and SAF, whereas, it was $75 \mathrm{~m}$ and $100 \mathrm{~m}$ at the PF1 and PF2, respectively. These variations in DCM could be linked to the variation in MLD of the respective fronts that can alter the nutrient flux along with photic depth. The diagnostic pigment indices showed highest abundance of diatoms at the PF1 and PF2, while the flagellates and prokaryotes were predominant at the STF and SAF regions, respectively. Unlike the diatoms and flagellates, the prokaryotes were found low in concentration, especially at the PF. These results indicate the niche preference of specific groups (Mishra et al., 2016). However, the diatoms abundance was always lower at the surface water compared to the depth in the frontal regions. Abundances of phytoplankton community at different depths might be the consequence of phytoplankton adaptations to the environmental conditions of the region. The flagellates abundance showed opposite trend to the diatoms both at the surface and water column. The prokaryotes decreased from STF to PF2 at the surface and showed their abundance at a depth of $30 \mathrm{~m}$ in the STF and $100 \mathrm{~m}$ at SAF, PF1 and PF2. Such information on group distribution and its percentage contribution with respect to region and related environmental conditions would provide refined knowledge on phytoplankton community dynamics and its role in biogeochemistry of the given area. Combined analysis of in situ and satellite-based phytoplankton pigment data for the period 1998-2014 indicated that the diatoms abundance increased at the STF and decreased at the SAF and the PF. On the other hand Mishra et al. (2015) showed that the chlorophytes abundance increased at STF, SAF and PF, revealing a shift in phytoplankton communities along the fronts. They suggested that the diatom community in the SO was adapted to a wide range of temperature at various frontal regions, indicating the mechanism of cold adaptation. On the other hand, the chlorophytes growth was restricted at the PF due to lack of cold adapted species in the community.

Daily integrated surface photosynthetically active radiation (PAR) showed clear latitudinal variation and ranged from 16.58 to $65.99(39.82 \pm 14.52$ $\left.\mathrm{E} \mathrm{m}^{-2} \mathrm{~d}^{-1}\right)$. Although, overall decreasing trend $\left(\mathrm{R}^{2}=\right.$ $0.56)$ was observed from lower $\left(0.12^{\circ} \mathrm{S}\right)$ to higher 
$\left(56.58^{\circ} \mathrm{S}\right)$ latitudes, intermittent higher values of daily PAR were also recorded at higher latitudes, especially in the STF and SAF regions (Tripathy et al., 2016). Irregular variation of daily PAR could mainly be ascribed to the overcast sky. Towards south, the overcast condition was more prevalent, particularly in the PF region. The variation of column-integrated PP (IPP) showed clear distinction among fronts with higher values at STF and SAF compared to PF region. The IPP ranged from 29.17 to $325.54(124 \pm 86.34 \mathrm{mg}$ $\mathrm{C} \mathrm{m}^{-2} \mathrm{~d}^{-1}$ ) in these regions. No clear relationship was observed between daily PAR and corresponding daily IPP and column-integrated Chl-a ( $\left.\mathrm{Chl}_{\text {int }}\right)$ indicating that factor(s) other than surface light contributing towards IPP and $\mathrm{Chl}_{\text {int }}$ variation in the study area. In the $\mathrm{PF}$ region, especially at $50^{\circ} .75^{\prime} \mathrm{S}$ and $52^{\circ} .43^{\prime} \mathrm{S}$ despite high $\mathrm{Chl}_{\text {int }}$ the IPP was low, which could be ascribed to cloud-induced very low daily PAR (18.31 and $18.59 \mathrm{E} \mathrm{m}^{-2} \mathrm{~d}^{-1}$, respectively) at those locations. Moreover, IPP and corresponding $\mathrm{Chl}_{\text {int }}$ did not show any correlation between them, thereby corroborating the hypothesis proposed by Tripathy et al. (2014), that high biomass does not always lead to high PP in the study area. The relationship between surface PP $\left(\mathrm{PP}_{0}\right)$ and daily PAR did not show light limitation. $\mathrm{PP}_{0}$ showed moderately strong positive relationship $\left(\mathrm{R}^{2}=0.63\right)$ with surface $\mathrm{Chl}-\mathrm{a}\left(\mathrm{Chl}_{0}\right)$ signifying that $\sim 60 \%$ of the variance in $\mathrm{PP}_{0}$ can be explained by phytoplankton biomass only. From the present observations the authors inferred that (1) very low surface PAR resulted in low IPP, otherwise light limitation is unlikely during clear sky conditions of the austral summer, (2) intensity of surface PAR had a reasonable control on surface PP; whereas it had inconsequential effect on water column-integrated productivity.

During the investigation, a total of 47 species of zooplankton (copepods were dominant) were recorded from all stations which includes calanoida (27), cyclopoida (9), poicelostomatoida (4), harpacticoida (3), chaetognatha (2) and appendicularins (2). Species diversity and dominance ranged from 0.12 to 1.05 and from 0.1 to 0.88 , respectively (Fig. 5). Maximum species diversity was found at PF2 and the minimum at PF1. Calanoida (56\%) followed by cyclopoida (38\%) represented the total zooplankton community at the STF; whereas, at the SAF cyclopoida (65\%) and Calanoida (25\%) were the dominant groups. On the other hand at PF1 and PF2 calanoida and

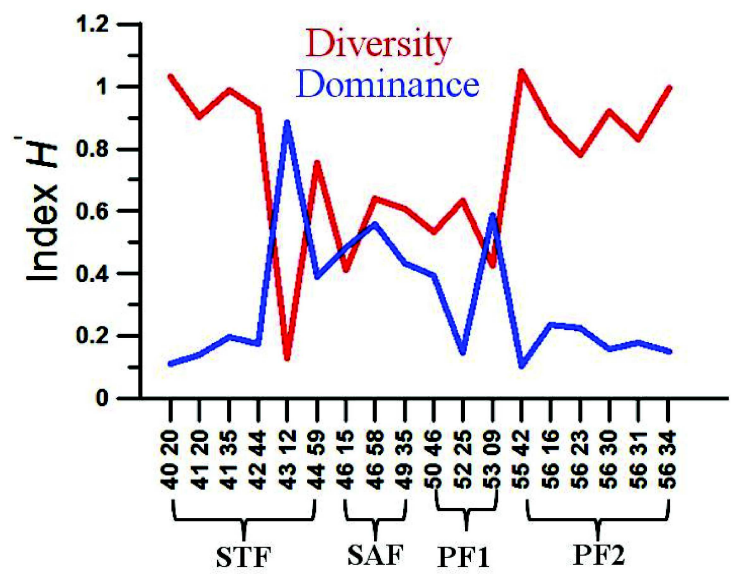

Fig. 5: Variation of zooplankton species diversity and dominance at different frontal regions of the Indian sector of SO

cyclolpoida comprise $50 \%$ and $45 \%$ of the total zooplankton community, respectively (Venkataramana et al., 2016). The higher abundance of zooplankton observed at PF2 coincided with the peak of phytoplankton density. Presence of high zooplankton biomass at PF2 might lower the level of Chl-a. In this region, grazing pressure might be higher than the phytoplankton growth rate in presence of high nutrients. Highest Chl-a concentration was observed at PF1 coinciding with low zooplankton biomass, indicating that control of autotrophic production was mainly depending on either presence of high nutrients and/or zooplankton abundance. Macro-zooplankton were often second only to copepods in abundance and biomass. Their population density was low due to their inability to adapt to the prevailing environmental conditions. The predominant species were Mesosagitta minima, Sagitta sp., Oikopleura gracillis and $O$. labradoriensis.

In continuation to $e x$-situ experiment conducted by Ramaiah et al. (2015) at STF, a similar approach was used to study the response of bacterial and phytoplankton community to micronutrient amendments at the PF. Results indicated a significant increase in phytoplankton biomass in all micronutrient amendments as compared to the control. Furthermore, it was observed that autotrophic process in the PF was not only limited by $\mathrm{Fe}$, but also by $\mathrm{Co}$ and $\mathrm{Cu}$ (Jain et al., 2015).

The absorption coefficients of phytoplankton specific absorption at $440 \mathrm{~nm}, \mathrm{a}_{\mathrm{ph}}^{*}(440)$ were within 
the limits reported earlier. The study reported, Chl-a specific phytoplankton absorption, $\mathrm{a}^{*}{ }_{\mathrm{ph}}(440)$ for microphytoplankton between $0.03-0.26 \mathrm{~m}^{2} \mathrm{mg}^{-1}$, nanofractions between $0.029-0.135 \mathrm{~m}^{2} \mathrm{mg}^{-1}$ and for total phytoplankton between $0.008-0.17 \mathrm{~m}^{2} \mathrm{mg}^{-1}$ (Minu et $a l ., 2016)$. This study showed that in the red region $\mathrm{a}^{*}{ }_{\mathrm{ph}}(665)$ were quite higher than the earlier reports. This high $\mathrm{a}^{*}{ }_{\mathrm{ph}}$ could be a result of pigment packaging. Absorption by picophytoplankton showed typical spectra similar to that of total particulate matter except in the case of distinct peaks of Chl-a. Pico fractions had a negligible amount of Chl-a concentration which may have resulted in low absorption by Chl-a in the $440 \mathrm{~nm}$ range. Phycoerythrobilins have absorption peaks at 540-546 $\mathrm{nm}$ and around 615-645 $\mathrm{nm}$. Phaeophytin and phaeophorbide have maximum absorption at $665 \mathrm{~nm}$ apart from Chl-a. It is suggested that cyanobacteria of pico size dominating with phycoerythrobilins and phaeophytins may have constituted the fractions in the study region. The absorption coefficients of detritus were lower for size fractions examined than reported earlier. The authors suggested that, as this region is isolated from any kind of terrestrial influence the possible ways of detritus input in the study area could be from autochthonous source.

\section{Summary}

The SO plays a fundamental role in the functioning of the earth system, influencing climate, sea level, biogeochemical cycles, and biological productivity on a variety of scales. Usually an ecosystem would be dictated, in the first instance, by the sensitivity of thriving organisms to the changing physical environment. The overall dynamics of the system would then be determined by the influence of affected species on other species in the food-web, whether that influence is as predators, prey, competitors, ecological succession or in some other role. In SO along with seasonal variability, inter-annual variability is a natural feature of the region, including variability in the Southern Annular Mode, strength of the ACC, maximum sea ice extent, and productivity. The combination of these factors can give rise to large variations in ecological changes over time. However, attributing ecological change(s) as impacts of climate change is a challenging task, faced by the modern oceanographic fraternity, because results between regions and across years are variable and, often ambiguous.

In this context, scanty information on the Indian sector of SO are available on particular aspects of ecosystems, such as controls on variability in phytoplankton and zooplankton community, food-web dynamics, primary production, in-water constituents that compete with phytoplankton for utilisation of light, the distribution of Antractic krill, copepod lifecycles, grazing pressure and other predator foraging and life cycles. Outcomes from the Indian Southern Ocean Expeditions conducted during 2009 to 2013 certainly forms a good first hand baseline dataset to get an overall preliminary picture of the Indian sector of SO processes that are responsible for modulating the biological productivity and biogeochemistry of this region. It summarizes by considering the general nature of SO food-webs and the regional/frontal differences in the ecosystems. The study area extended between the $40^{\circ} \mathrm{S}$ to $66^{\circ} \mathrm{S}$ along the meridional transect between $47^{\circ} \mathrm{E}$ and $57^{\circ} 3^{\prime} \mathrm{E}$, wherein point sampling and time series observations were carried out. Biomass and community structure of plankton, primary productivity, carbon flux, food-web dynamics, bacterial phylogenetic diversity, biochemical composition of krills and squids, and survey of mammals and birds were some of the major areas of investigation. However, no studies have been initiated to investigate benthic life forms, benthic-pelagic coupling and its role in carbon cycle.

The SO ecosystem is generally assumed to be controlled by the supply of macro and micro-nutrients and light that are essential for phytoplankton photosynthesis. This bottom-up control suggests that the ecosystem would be sensitive to changes in physical forcings that influence the light and nutrient environment experienced by phytoplankton (upwelling, varying MLD, melt/spread of sea ice). The phytoplankton performs essential role in controlling the biological fluxes and export of carbon and nutrients from the ocean surface to the deep interior. In addition, predators exert controls on ecosystem structure and function (top-down control), which contribute to ecosystem variability. To differentiate between bottom-up and top-down controls, further integrated observations of physics, chemistry and biology across multiple trophic levels are required, which would in turn facilitate better understanding of the biogeochemical process of the Indian sector of SO. 
Considering the overall results from above expeditions (only those variables which were repeated in all the expeditions), we can infer that the Indian sector of SO has marked temperature gradient zonation from STF to PF. These zones provide different environmental settings that will have an influence on the biota present in that region. It's evident that the phytoplankton community structure follows the similar pattern of dominance in all the observations carried out in different expeditions. The flagellates being dominated at STF and diatoms at PF. Similarly, the primary productivity results indicated the PF being more productive as compared to STF (Table 2). Whereas, zooplankton community was dominated with copepod in both the fronts, however, the microzooplankton community was dominant at STF as compared to PF. The results on food web dynamics indicate that the STF was influenced by microbial food web and conventional food web whereas; PF was mainly by conventional food web. The variation of such food webs and the phytoplankton biomass was complimenting vice versa role of the predator-prey relationship. However, the long-term satellite and NOBM data indicates the break in the pattern of phytoplankton community dominance albeit the results need to be validated with in situ observations those will be carried out in future expeditions.

Since the ISOE time is limited to austral summer
(January-March) only, there is non-availability of data on the variability in the in situ conditions during rest of the seasons. Thus, to bridge the gap of in situ data collection on oceanographic variables, year-round mooring, simulation/modelling of the study area is a prerequisite for effective monitoring and assessment of current and future climate change impacts. Necessarily, the design of the field program would benefit from the current understandings about how the $\mathrm{SO}$ ecosystem is responding to alterations in climate change. Plans are under process to deploy sensors attached to autonomous ocean profiling floats (such as Argo), line mooring, and autonomous underwater vehicles (glider) so as to increase spatial as well as temporal observations of oceanic realm, which would facilitate validation of observation from space-borne ocean color sensors.

\section{Acknowledgements}

Grateful acknowledgments are expressed to the Secretary, Ministry of Earth Sciences, and the Director, ESSO-NCAOR for their support and encouragement for this work. We thankfully acknowledge each and every author, whose published contributions are summarized and cited in this document. Sincere thanks are extended to all the members of Indian Southern Ocean Expeditions for their excellent co-operation. This is ESSO-NCAOR contribution number 35/2016.

Table 2: Comparison of phytoplankton productivity at different frontal zones of the Indian sector of SO

\begin{tabular}{|c|c|c|c|c|c|}
\hline \multirow[t]{2}{*}{ Frontal Zone } & \multicolumn{3}{|c|}{ Primary productivity $(\mathrm{PP})$} & \multirow[t]{2}{*}{ Remarks } & \multirow[t]{2}{*}{ Reason } \\
\hline & $\mathrm{a}$ & $\mathrm{b}$ & $\mathrm{c}$ & & \\
\hline $\begin{array}{l}\text { STZ (north } \\
\text { of STF) }\end{array}$ & $\begin{array}{l}200 \mathrm{mgC} \\
\mathrm{m}^{-2} \mathrm{~d}^{-1}\end{array}$ & $\begin{array}{l}\sim 185 \\
\mathrm{mgC} \mathrm{m}^{-2} \mathrm{~d}^{-1}\end{array}$ & - & Low PP & Nutrient Limitation, High stability due to stratification \\
\hline $\begin{array}{l}\text { STFZ (zone } \\
\text { between } \\
\text { SSTF \& ARF) }\end{array}$ & $\begin{array}{l}300-400 \\
\mathrm{mgC} \mathrm{m}^{-2} \mathrm{~d}^{-1}\end{array}$ & $\begin{array}{l}210 \\
\mathrm{mgC} \mathrm{m} \mathrm{m}^{-2} \mathrm{~d}^{-1}\end{array}$ & $\begin{array}{l}152 \\
\mathrm{mgC} \mathrm{m} \mathrm{m}^{-2} \mathrm{~d}^{-1}\end{array}$ & Low PP & Nutrient Limitation \\
\hline SSTF & $\begin{array}{l}>900 \\
\mathrm{mgC} \mathrm{m}^{-2} \mathrm{~d}^{-1}\end{array}$ & $\begin{array}{l}>900 \\
\mathrm{mgC} \mathrm{m}^{-2} \mathrm{~d}^{-1}\end{array}$ & - & High PP & $\begin{array}{l}\text { Supply of nutrients along with key micro-nutrients (e.g., Fe) } \\
\text { from the Antarctic bottom water. An additional supply of some } \\
\text { key micronutrients by the ARC from the African continent and } \\
\text { the presence of the Crozet Island }\end{array}$ \\
\hline $\begin{array}{l}\text { PFZ (zone } \\
\text { including } \\
\text { PF and SAF) }\end{array}$ & $\begin{array}{l}<200 \\
\mathrm{mgC} \mathrm{m}^{-2} \mathrm{~d}^{-1}\end{array}$ & $\begin{array}{l}340 \\
\mathrm{mgC} \mathrm{m}\end{array}$ & $\begin{array}{l}210 \\
\mathrm{mgC} \mathrm{m} \mathrm{m}^{-2} \mathrm{~d}^{-1}\end{array}$ & Low PP & $\begin{array}{l}\text { Grazing by zoo-plankton and Fe limitation. However the } \\
\text { persistent TML supports relatively higher column PP than STF }\end{array}$ \\
\hline $\begin{array}{l}\text { ANZ (zone } \\
\text { between } \\
\text { Antarctic } \\
\text { continent \& P }\end{array}$ & - & $\begin{array}{l}\sim 190 \\
\mathrm{mgC} \mathrm{m}^{-2} \mathrm{~d}^{-1}\end{array}$ & $\begin{array}{l}387 \& 1083 \\
\mathrm{mgC} \mathrm{m}^{-2} \mathrm{~d}^{-1}\end{array}$ & $\begin{array}{l}\text { Relatively } \\
\text { low PP }\end{array}$ & Light limitation, and pigment packaging effect in large plankton \\
\hline
\end{tabular}

*a: Jasmine et al. (2009); b: Gandhi et al. (2012); c: Tripathy et al. (2014, 2015) 


\section{References}

Bandopadhyay R, Shukla P, Gupta P and Singh N (2014) Isolation and Molecular Characterization of Novel Microalgal Species from Southern Ocean towards Exploring their Metabolic Potential and Biological Variability In: Technical Report of the $5^{\text {th }}$ Indian Southern Ocean Expedition (Eds. Anilkumar N and Achuthankutty CT) ISBN: 978-93-5156520-8 pp 53-56

Chisholm S W, Falkowski P G and Cullen J J (2001) Discrediting Ocean Fertilization Science 294 309-310

Gandhi N, Ramesh R, Laskar A H, Sheshshayee M S, ShetyeS, Anilkumar N, Patil S M and Mohan R (2012) Zonal variability in primary production and nitrogen uptake rates in the southwestern Indian Ocean and the Southern Ocean. Deep-Sea Research I 67 32-43

Garcia R A, Fearns P R C and Mckinna L I W (2014) Challenges in detecting trend and seasonal changes in bathymetry derived from HICO imagery: a case study of Shark Bay, Western Australia Remote Sens Environ 147C 186-205

Grant S A, Constable B, Raymond and Doust S (2006) Bioregionalisation of the Southern Ocean Report of Experts Workshop WWF-Australia and ACE CRC Hobart pp 48

Griffiths H J, Barnes D K A and Linse K (2009) Towards a generalised biogeography of the Southern Ocean benthos $J$ Biogeogr 36 162-177

Haridevi C K, Naik R K and Achuthankutty C T (2015) Photosynthetic efficiency of phytoplankton in the Indian sector of Southern Ocean during austral summer 2012. In: Technical Report of the $6^{\text {th }}$ Indian Southern Ocean Expedition (Eds. Anilkumar N and Achuthankutty CT) ISBN: 978-93-5212-562-3 pp 19-24

Jain A, Meena R M, Naik R K, Gomes J, Bandekar M, Bhat M, Mesquita A and Ramaiah N (2015) Response of polar front phytoplankton and bacterial community to micronutrient amendments Deep Sea Res II 118 197-208

Jasmine P, Muraleedharan K R, Madhu, N V, Asha Devi C R, Alagarswamy R, Achuthankutty C T, Jayan Z, Sanjeevan V N and Sahayak S (2009) Hydrographic and productivity characteristics along $45^{\circ} \mathrm{E}$ longitude in the southwestern Indian Ocean and Southern Ocean during Austral summer 2004 Mar Ecol Prog Ser 389 97-116

Jayabaskaran S (2014) Relationship between Oceanographic parameters and Deep Sea Megafauna and Marine Mammals of Southern Ocean In: Technical Report of the $5^{\text {th }}$ Indian Southern Ocean Expedition(Eds. Anilkumar N and Achuthankutty CT) ISBN: 978-93-5156-520-8 pp 63-70

Kostianoy A G, Ginzburg A I, Lebedev S A, Frankignoulle M and Delille B (2003) Fronts and mesoscale variability in the southern Indian Ocean as inferred from the TOPEX/ POSEIDON and ERS-2 altimetry data Oceanology 43 632642

Krishnan K P, Sinha R K, Nair S, Noronha S B, Chacko R and Anilkumar N (2014) Carbon demand utilization and metabolic diversity of bacterioplankton in the frontal regimes of the Indian sector of Southern Ocean Ann Microbiol DOI 10.1007/s13213-014-0948-2

Manjebrayakath H (2014) Role of Antarctic krills in the biogeochemical cycle in the Indian sector of Southern Ocean In: Technical Report of the $4^{\text {th }}$ Indian Southern Ocean Expedition (Eds. Anilkumar N and Achuthankutty CT) ISBN: 978-93-5156-583-3 pp 63-66

Mendes C R B, Kerr R, Tavano V M, Cavalheiro F A, Garcia C A E, Dessai D R G and Anilkumar N (2015) Cross-front phytoplankton pigments and chemotaxonomic groups in the Indian sector of the Southern Ocean Deep Sea Res II 118 221-232

Minu P, Souda V P, Mishra R K, Anilkumar N and Ashraf M P (2016) Size fractionated phytoplankton and its optical properties in the Indian sector of Southern Ocean In: Technical Report of the $7^{\text {th }}$ Indian Southern Ocean Expedition (Eds. Anilkumar N and Tripathy SC) ISBN: 978-93-5267-057-4 pp 48-57

Minu R L, Gopalakrishnan T, Asha Devi C R, Pillai H U K, Sanjeevan V N and Achuthankutty C T (2015) Micro and mesozooplankton community structure at the Suptropical and Polar Fronts during austral summer 2012 In: Technical Report of the $6^{\text {th }}$ Indian Southern Ocean Expedition (Eds. Anilkumar N and Achuthankutty CT) ISBN: 978-93-5212562-3 pp 25-29

Mishra R K, Naik R K and Anilkumar N (2016) Phytoplankton community distribution along the frontal regions of Indian Ocean Sector of Southern Ocean during Austral summer 2013 In: Technical Report of the $7^{\text {th }}$ Indian Southern Ocean Expedition (Eds. Anilkumar N and Tripathy SC) ISBN: 978-93-5267-057-4 pp 22-26

Mishra R K, Naik R K and Anilkumar N (2015) Adaptations of phytoplankton in the Indian Ocean sector of the Southern Ocean during austral summer of 1998-2014 Front Earth Sci $9742-752$

Naik R K, Bhaskar PV and Achuthankutty C T (2015a) Biological components In: Technical Report of the $6^{\text {th }}$ Indian Southern Ocean Expedition (Eds. Anilkumar N and Achuthankutty CT) ISBN: 978-93-5212-562-3 pp 11-18

Naik R K, George J V, Soares M, Devi A, Anilkumar N, Roy R, Bhaskar P V, Murukesh N and Achuthankutty C T (2015b) Phytoplankton community structure at juncture of the 
Agulhas Return Front and subtropical front in the Indian Ocean sector of Southern Ocean: Bottom-up and topdown control Deep Sea Res II 118 233-239

Patil S M, Mohan R, Shetye S, Gazi S and Jafar S (2014) Morphological variability of Emilianiahuxleyi in the Indian sector of the Southern Ocean during the austral summer of 2010 Mar Micropaleontol 107 44-58

Pavithran S, Pillai H U K, Bhaskar P V, Anilkumar N and Achuthankutty (2014b) Biological productivity and foodwed dynamics In: Technical Report of the $5^{\text {th }}$ Indian Southern Ocean Expedition (Eds. Anilkumar N and Achuthankutty CT) ISBN: 978-93-5156-520-8 pp 19-21

Pavithran S, Pillai H U K, Nanjkar M, Tripathy S C and Achuthankutty C T (2014a) Biological productivity of Indian sector Southern Ocean In: Technical Report of the $5^{\text {th }}$ Indian Southern Ocean Expedition (Eds. Anilkumar N and Achuthankutty CT) ISBN: 978-93-5156-520-8 pp 13-18

Pavithran S, Anilkumar N, Krishnan K P, Noronha S B, George J V, Nanajkar M, Chacko R, Desai D R G and Achuthankutty C T (2012) Contrasting pattern in chlorophyll a distribution within the Polar front of Indian Sector of Southern Ocean during Austral summer Curr Sci 102 899-903

Pillai H U K, Pavithran S, Tripathy S C and Achuthankutty C T (2014) Time series observation of mesozooplankton at STF and PF In: Technical Report of the $5^{\text {th }}$ Indian Southern Ocean Expedition (Eds. Anilkumar N and Achuthankutty CT) ISBN: 978-93-5156-520-8 pp 24-27

Pollard R T, Bathmann U, Dubischar C, Read J F and Lucas M (2002) Zooplankton distribution and behaviour in the Southern Ocean from surveys with a towed optical plankton counter Deep Sea Res II 49 3889-3915

Prasanna K, Ghosh P and Anil Kumar N (2015) Stable isotopic signature of Southern Ocean deep water $\mathrm{CO}_{2}$ ventilation Deep Sea Res II 118 177-185

Prasanna K, Ghosh P, Anil Kumar N and Dessai D R G (2014) $\mathrm{CO}_{2}$ uptake by Southern Ocean during austral summer of 2011 In: Technical Report of the $5^{\text {th }}$ Indian Southern Ocean Expedition (Eds. Anilkumar N and Achuthankutty CT) ISBN: 978-93-5156-520-8 pp 28-33

Pravin P, Aneeshkumar K V and Mennakumari B (2015) Squid Jigging Operations in the Indian Ocean Sector of Southern Ocean In: Technical Report of the $6^{\text {th }}$ Indian Southern Ocean Expedition (Eds. Anilkumar N and Achuthankutty CT) ISBN: 978-93-5212-562-3 pp 47-52

Ramaiah N, Jain A, Meena R M, Naik R K, Verma R, Bhat M, Mesquita A, Nadkarni AD, Souza S E, Ahmed T, Bandekar
M and Gomes J (2015b) Response of bacteria and phytoplankton from a subtropical front location Southern Ocean to micronutrient amendments ex situ, Deep Sea Res II 118 209-220

Ramaiah N, Jain A, Meena R M, Naik R K, Verma R, Bhat M, Mesquita A, Nadkarni A, D’Souza S E, Ahmed T, Bandekar M and Gomes J (2015a) Bacterial responses to nutrient alterations $e x$-situ and their phylogenetic diversity from subtropical front of Indian sector of Southern Ocean In: Technical Report of the $6^{\text {th }}$ Indian Southern Ocean Expedition (Eds. Anilkumar N and Achuthankutty CT) ISBN: 978-93-5212-562-3 pp 30-46

RemyaKumari K R, Asha K K, Aneeshkumar K V, Suseela M, Pravin P and Lakshmanan P T (2015) Biochemical Profiling of two Species of Squids (Ommastraphes bartramii) (Lesucur 1821) and Todarodes filippovea (Adam 1975) from the Indian Ocean sector of Southern Ocean In: Technical Report of the $6^{\text {th }}$ Indian Southern Ocean Expedition (Eds. Anilkumar N and Achuthankutty CT) ISBN: 978-93-5212-562-3 pp 53-56

Sabine C L, Feely R A, Gruber N, Key R M, Lee K, Bullister J L, Wanninkhof R, Wong C S, Wallace D W R, Tilbrook B, Millero F J, Peng T H, Kozyr A, Ono T and Rios A F (2004) The Oceanic Sink for Anthropogenic $\mathrm{CO}_{2}$ Science 305 367-371

Sarmiento J L, Hughes T M C, Stouffer R J and Manabe S (1998) Simulated response of the ocean carbon cycle to anthropogenic climate warming Nature 393 245-249

Shaju S S, Minu P, Ashraf P M and Beenakumari B (2014) Measurements of bio-optical parameters of Southern Ocean In: Technical Report of the $5^{\text {th }}$ Indian Southern Ocean Expedition (Eds. Anilkumar N and Achuthankutty CT) ISBN: 978-93-5156-520-8 pp 34-40

Shetye S and Mohan R (2014) Investigation-III: Silicoflagellates as Paleoclimatic indicators: A case study from the Indian sector of Southern Ocean In: Technical Report of the $4^{\text {th }}$ Indian Southern Ocean Expedition (Eds. Anilkumar $\mathrm{N}$ and Achuthankutty CT) ISBN: 978-93-5156-583-3 pp 28-30

Tripathy S C, Haridevi C K and Mishra R K (2016) Latitudinal distribution of surface PAR and its relation with phytoplankton biomass and productivity In: Technical Report of the $7^{\text {th }}$ Indian Southern Ocean Expedition (Eds. Anilkumar N and Tripathy SC) ISBN: 978-93-5267-0574 pp 27-29

Tripathy S C, Pavithran S, Sabu P, Pilai H U K, Dessai D R G and Anilkumar N (2015) Deep chlorophyll maximum and primary productivity in Indian Ocean sector of the Southern Ocean: Case study in the Subtropical and Polar 
Front during austral summer 2011 Deep Sea Res II 118 240-249

Tripathy S C, Pavithran S, Sabu S, Naik R K, Noronha S B, Bhaskar P V and Anilkumar N (2014) Is phytoplankton productivity in the Indian Ocean sector of Southern Ocean affected by pigment packaging effect? Curr Sc 107 10191026
Venkataramana V, Tripathy S C, Pillai H U K and Santhosh Kumar C (2016) Distribution of copepod community structure in frontal systems of the Indian Ocean sector of Southern Ocean In: Technical Report of the $7^{\text {th }}$ Indian Southern Ocean Expedition (Eds. Anilkumar N and Tripathy SC) ISBN: 978-93-5267-057-4 pp 30-36. 